Chemical Technology

Division

Chemical Technology

Division

Chemical Technology

Division

Chemical Technology

Division

Chemical Technology

Division

Chemical Technology

Division

Chemical Technology

Division

Chemical Technology

Division

Chemical Technology

Division

Chemical Technology

Division

Chemical Technology

Division

Chemical Technology

Division

Chemical Technology

Division

Chemical Technology

Division

Chemical Technology

Division

Chemical Technology

Division

\section{Operational Envelope for Studies Using Magnetite to Remove Strontium and Actinides from SRS Tank Waste}

\author{
by H. A. Arafat, A. V. Gelis, \\ and G F. Vandegrift
}

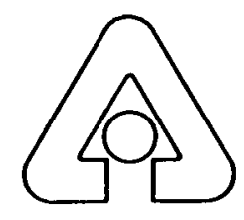

Argonne National Laboratory, Argonne, Illinois 60439

operated by The University of Chicago

for the United States Department of Energy under Contract W-31-109-Eng-38

Chemical Technology

Division

Chemical Technology

Division

Chemical Technology

Division

Chemical Technology

Division 
Argonne National Laboratory, with facilities in the states of Illinois and Idaho, is owned by the United States Government and operated by The University of Chicago under the provisions of a contract with the Department of Energy.

\begin{tabular}{l} 
DISCLAIMER \\
This report was prepared as an account of work sponsored by an agency of \\
the United States Government. Neither the United States Government nor \\
any agency thereof, nor The University of Chicago, nor any of their \\
employees or officers, makes any warranty, express or implied, or assumes \\
any legal liability or responsibility for the accuracy, completeness, or \\
usefulness of any information, apparatus, product, or process disclosed, or \\
represents that its use would not infringe privately owned rights. Reference \\
herein to any specific commercial product, process, or service by trade name, \\
trademark, manufacturer, or otherwise, does not necessarily constitute or \\
imply its endorsement, recommendation, or favoring by the United States \\
Government or any agency thereof. The views and opinions of document \\
authors expressed herein do not necessarily state or reflect those of the \\
United States Government or any agency thereof, Argonne National \\
Laboratory, or The University of Chicago. \\
\hline
\end{tabular}

Available electronically at http://www.doe.gov/bridge

Available for a processing fee to U.S. Department of Energy and its contractors, in paper, from:

U.S. Department of Energy

Office of Scientific and Technical Information

P.O. Box 62

Oak Ridge, TN 37831-0062

phone: (865) 576-8401

fax: (865) 576-5728

email: reports@adonis.osti.gov 


\begin{abstract}
ANL-02/30
ARGONNE NATIONAL LABORATORY

9700 South Cass Avenue

Argonne, IL 60439

\section{OPERATIONAL ENVELOPE FOR STUDIES USING MAGNETITE TO REMOVE STRONTIUM AND ACTINIDES FROM SRS TANK WASTE}

by

H. A. Arafat, A. V. Gelis, and G. F. Vandegrift
\end{abstract}

May 15, 2002 


\section{CONTENTS}

$\underline{\text { Page }}$

ABSTRACT . .

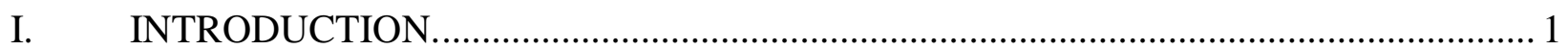

II. OPERATIONAL ENVELOPE FOR STRONTIUM AND ACTINIDE REMOVAL USING IN-SITU FORMED MAGNETITE ……………………………………….... 2

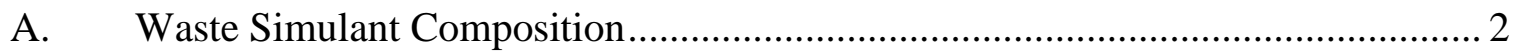

B. Radionuclide Concentrations and Oxidation States in the Waste Simulant............ 3

C. Decontamination Factor Requirements ……………....................................... 5

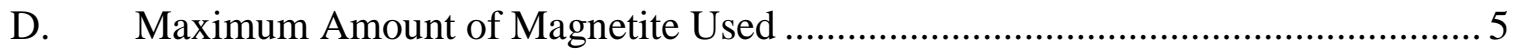

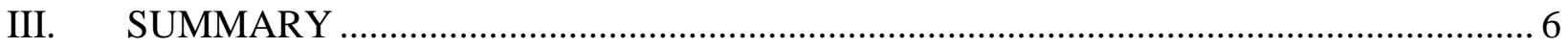

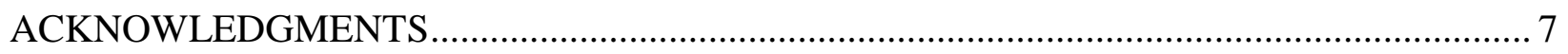

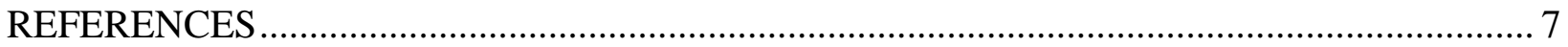

APPENDIX A. SRS RECIPE FOR WASTE SIMULANT PREPARATION ……................... 9 


\section{TABLES}

No.

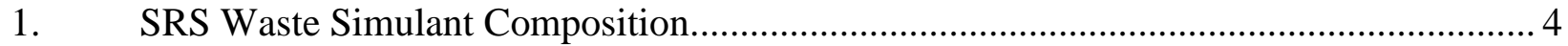

2. Concentrations and Oxidation States for Radionuclides ................................................... 4

3. Decontamination Factor Required for Various Radionuclides .......................................... 5 


\title{
OPERATIONAL ENVELOPE FOR STUDIES USING MAGNETITE TO REMOVE STRONTIUM AND ACTINIDES FROM SRS TANK WASTE
}

\author{
by \\ H. A. Arafat, A. V. Gelis, and G. F. Vandegrift \\ Chemical Technology Division \\ Argonne National Laboratory \\ Argonne, IL 60439
}

May 15, 2002

\begin{abstract}
This work discusses the operational envelope developed for tests involving in-situ formed magnetite to remove strontium $(\mathrm{Sr})$ and actinide from Savannah River Site (SRS) waste solution. These tests will be performed at Argonne National Laboratory (ANL) in support of the SRS effort for HLW treatment. The operational envelope was developed in consultations with key personnel at SRS. Four elements of the operational envelope were identified: (1) waste simulant composition, (2) radionuclide concentrations and oxidation states, (3) minimum DF requirements, and (4) the maximum amount of magnetite that can be used per liter of waste.
\end{abstract}

\section{INTRODUCTION}

Nearly 34 million gallons of radioactive waste are currently stored in tanks at the Savannah River Site (SRS) in South Carolina. This waste, which is a product of the cold-war era, contains a significant inventory of hazardous radioactive isotopes. Radionuclides of special concern are cesium $\left({ }^{137} \mathrm{Cs}\right)$, strontium $\left({ }^{90} \mathrm{Sr}\right)$, and three transuranic (TRU) elements, neptunium $\left({ }^{237} \mathrm{~Np}\right)$, plutonium $\left({ }^{238,239} \mathrm{Pu}\right)$, and americium $\left({ }^{241} \mathrm{Am}\right)$. At the Savannah River Site (and at Hanford), the plan is to separate this waste into a high-level waste (HLW) stream that will contain most of the Cs, Sr, and actinide elements, and a low-level waste (LLW) stream that will contain a high fraction of the inert waste constituents. Because of the high cost associated with disposal of the HLW, it is essential to minimize its volume. The current SRS 
plan is to remove $\mathrm{Sr}$ and actinides ( $\mathrm{Pu}, \mathrm{Am}, \mathrm{Np}$ ) from the alkaline HLW using powdered monosodium titanate (MST) in a stirred tank [HOBBS-1992, -1993, and -1999]. Although

uranium $\left({ }^{235,238} \mathrm{U}\right)$ is not an isotope of special concern, its removal by MST is tracked since it is removed, on a mass basis, more than the other alpha emitters. However, according to SRS, uranium removal is not needed to meet current regulatory commitments [FINK-2002].

A number of cost and technical risk issues are associated with the MST technology. These issues include slow kinetics for Pu removal, low actinide loadings, slow filtration, and MST batch consistency. Additionally, limited titanium solubility in the glass is another major process risk. In order to reduce or eliminate the risks for the baseline $\mathrm{Sr}$ and actinide removal process, SRS is considering alternative technologies to replace the current MST technology. Alternative technologies include using sodium permanganate or in-situ formed magnetite for $\mathrm{Sr}$ and actinide removal. The latter is considered in this report.

This report summarizes the outcome of the first task of the magnetite process study, which is to establish the operational envelope for the process laboratory tests. This includes identifying a suitable waste simulant composition and determining the concentrations and oxidation states of the radionuclides to be studied, the limit on the amount of magnetite added per liter of waste feed, and the decontamination factors for the radionuclides to be tested. The boundaries of this operational envelope were decided upon after consultation with key personnel at SRS.

\section{OPERATIONAL ENVELOPE FOR STRONTIUM AND ACTINIDE REMOVAL USING IN-SITU FORMED MAGNETITE}

Four elements of the operational envelope were identified: (1) waste simulant composition, (2) radionuclide concentrations and their oxidation states in the waste simulant, (3) decontamination factor (DF) requirements, and (4) maximum amount of magnetite used per liter of waste. Following is a discussion of each of these elements.

\section{A. Waste Simulant Composition}

A recipe for the caustic waste simulant to be used in the experimental work was obtained from David Hobbs (SRS) [HOBBS-2002]. The simulant composition is identical to 
that used by SRS in the baseline MST tests. This simulant was chosen, after discussions with SRS, for the following reasons:

- By using the same simulant that SRS used in their tests, a comparison could be established between the magnetite performance and that of MST or sodium permanganate.

- This simulant composition provides high solubility of the actinides of interest, based largely on extensive studies of plutonium solubility. It is worth mentioning, however, that $\mathrm{Pu}$ concentrations in actual waste can greatly exceed its concentration in the simulant.

- The simulant composition is reasonably close to the average composition of waste.

- This simulant was found to be stable after filtration (i.e., no salt precipitation) within a reasonable amount of time (up to few weeks).

Salt concentrations in the simulant are shown in Table 1. The detailed preparation procedure is provided in Appendix A. It is worth mentioning that, while the majority of the SRS tests using MST involved measuring the DF values for all radionulides in solution at the same time, we will be studying the removal of these isotopes one at a time. This will enable us to use radiation-counting techniques that are more accurate than inductively coupled plasma-mass spectrometry (ICP-MS). We will perform parallel tests using MST to establish a comparison. Also, some tests will be performed with all radionuclides present in solution and will be directly compared with the SRS results for MST.

\section{B. Radionuclide Concentrations and Oxidation States in the Waste Simulant}

In this work, we will study the removal of $\mathrm{Sr}, \mathrm{Pu}, \mathrm{U}, \mathrm{Np}$, and $\mathrm{Am}$ from waste simulant. Isotopes with suitable half-lives will be used to facilitate the concentration measurements. Table 2 shows the initial concentrations of the isotopes in the waste simulant and the oxidation states to be tested. These concentrations are similar to those tested at SRS, which will help establish a comparison with the MST process. Note that $\mathrm{Pu}(\mathrm{IV})$ behaves in similar fashion to $\mathrm{Np}(\mathrm{IV})$ from a precipitation standpoint and, therefore, will be used as a surrogate for $\mathrm{Np}(\mathrm{IV})$.

At SRS, Am is not tested separately, but the total alpha activity of the Pu/Am sample is monitored. Am is believed to be present at trace concentration in these samples. 
Table 1. SRS Waste Simulant Composition

\begin{tabular}{|c|c|}
\hline Component & $\begin{array}{c}\text { Solution } \\
\text { Concentration (M) }\end{array}$ \\
\hline Free $\mathrm{NaOH}$ & 1.33 \\
\hline Total $\mathrm{NaNO}_{3}$ & 2.60 \\
\hline $\mathrm{NaAl}(\mathrm{OH})_{4}$ & 0.43 \\
\hline $\mathrm{NaNO}_{2}$ & 0.13 \\
\hline $\mathrm{Na}_{2} \mathrm{SO}_{4}$ & 0.52 \\
\hline $\mathrm{Na}_{2} \mathrm{CO}_{3}$ & 0.026 \\
\hline $\mathrm{Total}_{\mathbf{N a}}$ & $\mathbf{5 . 6}$ \\
\hline
\end{tabular}

Table 2. Concentrations and Oxidation States for Radionuclides

\begin{tabular}{|c|c|c|}
\hline Radionuclide & $\begin{array}{c}\text { Solution } \\
\text { Concentration }\end{array}$ & Oxidation State \\
\hline $\mathrm{Sr}$ & 0.1 to $0.6 \mathrm{mg} / \mathrm{L}^{(\text {a) }}$ & II \\
\hline $\mathrm{Pu}$ & $0.2 \mathrm{mg} / \mathrm{L}$ & IV, VI \\
\hline $\mathrm{Np}$ & $0.5 \mathrm{mg} / \mathrm{L}$ & V, VI \\
\hline $\mathrm{U}$ & $10.0 \mathrm{mg} / \mathrm{L}^{\text {(b) }}$ & VI \\
\hline $\mathrm{Am}$ & Up to $0.2 \mathrm{mg} / \mathrm{L}$ & III \\
\hline
\end{tabular}

(a) Total $\mathrm{Sr}$, including $\mathrm{Sr}-85$ tracer.

(b) As uranyl nitrate hexahydrate. 


\section{Decontamination Factor Requirements}

Decontamination factor (DF) is defined as the initial radionuclide concentration in the solution divided by its final concentration after treatment. The targeted DF values for this work are based on the needs identified by SRS [HARMON-2002]. SRS has performance requirements for the final concentrations of $\mathrm{Sr}$ and total alpha in solution. The current limits are $120 \mathrm{nCi} / \mathrm{g}$ for ${ }^{90} \mathrm{Sr}$ and ${ }^{90} \mathrm{Y}$ and $20 \mathrm{nCi} / \mathrm{g}$ for total alpha. In order to quantify the removal requirements for the individual isotopes, based on the overall performance requirements, SRS has defined two DF values for all radionuclides of interest, "average DF" and "upper bound DF" [HARMON-2002]. These are listed in Table 3. The upper bound DF values were used as guidance for us to determine the minimum DF values for our tests, which are also listed in Table 3. Initially, we decided that for the magnetite process to be judged successful, it should achieve at least the upper bound DF value set by SRS for all radionuclides tested. However, after consultation with SRS personnel, they indicated that the magnetite process would be a viable alternative if it achieves $\mathrm{Pu} \mathrm{DF}>12$, if it filters better than MST.

Table 3. Decontamination Factor Required for Various Radionuclides

\begin{tabular}{|c|c|c|}
\hline & $\begin{array}{c}\text { SRS DF } \\
\text { Requirements } \\
\text { (average/upper } \\
\text { bound) }\end{array}$ & $\begin{array}{c}\text { Minimum ANL DF } \\
\text { Requirements for } \\
\text { Magnetite Process }\end{array}$ \\
\hline $\mathrm{Sr}$ & $1 / 5.1$ & 6 \\
\hline $\mathrm{Pu} / \mathrm{Am}$ & $12 / 49$ & 50 \\
\hline $\mathrm{Np}$ & $1 / 2$ & 3 \\
\hline $\mathrm{U}$ & $1 / 1$ & 3 \\
\hline
\end{tabular}

\section{Maximum Amount of Magnetite Used}

The effect of adding magnetite to the HLW on the subsequent performance of the glass plant has not been sufficiently investigated. This is proposed as a future study, should the magnetite process prove to be promising for $\mathrm{Sr}$ and actinide removal. Nonetheless, based on 
discussions with Dr. John Plodinec [PLODINEC-2002], from Mississippi State University, and Sam Fink [FINK-2002] and Sharon Marra [MARRA-2002], from SRS, some potential impacts of the presence of magnetite in the glass plant feed were identified.

The primary impact is that, although typical waste glass compositions can dissolve significant quantities of iron oxide, if the iron is in the form of magnetite its dissolution in glass is very slow. This can lead to a competition between the rate of dissolution and the sedimentation velocity of these particles. If magnetite particles accumulate in the melter, the magnetite layer at the bottom of the melter interferes with normal current flow, leading to reduced melt rates and eventually to failure of the melter. There are two key ways to solve this problem; the amount of magnetite is to be limited to $2 \%$ of the total iron content in the glass, which averages about 11-15 wt $\%$ of the glass weight [MARRA-2002], or the size of the magnetite particles has to be controlled. Smaller particles dissolve more easily in the melter.

Based on preliminary material balance calculations, performed by Sam Fink (SRS), the maximum amount of iron added to the waste solution, as a result of the magnetite process, will be $2.2 \mathrm{~g}$ Fe per liter of waste. This value was obtained based on the flowsheet for the In-Tank Precipitation (ITP) process, which shows an iron flow rate of $19.22 \mathrm{lb} / \mathrm{hr}$ to the glass plant. Assuming $2 \%$ of that value, the magnetite feed rate can be up to $0.384 \mathrm{lb} \mathrm{Fe} / \mathrm{hr}$. Hence, if all the iron added to the solution was converted to magnetite, the maximum amount of magnetite to be used is $3.04 \mathrm{~g}$ magnetite per liter of solution.

\section{SUMMARY}

In this report, the operational envelope was developed for tests on using in-situ formed magnetite for removal of Sr and actinides from SRS tank waste. This envelope was developed in consultation with key personnel at SRS. The four elements of the operational envelope were identified as (1) waste simulant composition, (2) radionuclides concentrations and oxidation state, (3) DF requirements, and (4) the maximum amount of magnetite that can be added per liter of waste.

The waste simulant will be prepared according to a recipe provided by SRS. The same recipe has been used in the MST tests at SRS. The total sodium concentration in the simulant is $5.6 \mathrm{M}$. In our tests, five radionuclides will be tested: $\mathrm{Sr}, \mathrm{Pu}, \mathrm{Np}, \mathrm{U}$, and $\mathrm{Am}$. The concentrations and oxidation states of the radionuclides in the simulant are as follows: $\mathrm{Sr}$ (II), 0.1 to $0.6 \mathrm{mg} / \mathrm{L} ; \mathrm{Pu}$ (IV, VI), $0.2 \mathrm{mg} / \mathrm{L} ; \mathrm{Np}$ (V, VI), $0.5 \mathrm{mg} / \mathrm{L} ; \mathrm{U}$ (VI), $10 \mathrm{mg} / \mathrm{L} ; \mathrm{Am}$ (III), up to $0.2 \mathrm{mg} / \mathrm{L}$. The targeted DF values, based on the needs at SRS, are as follows: DF $=6$ for 
$\mathrm{Sr}, \mathrm{DF}=50$ for $\mathrm{Pu} / \mathrm{Am}$, and $\mathrm{DF}=3$ for $\mathrm{Np}$ and $\mathrm{U}$. However, the magnetite process would be a viable alternative if it achieves $\mathrm{Pu} \mathrm{DF}>12$, if it filters better than MST. Finally, the maximum amount of iron added to the waste, as magnetite, should be equal or less than $2.2 \mathrm{~g}$ of Fe per liter of waste. This will limit the concentration of iron from the magnetite at $2 \%$ or less of the total iron in the feed to the glass plant. By keeping the iron concentration within this limit, potential risks associated with adding magnetite to the glass plant can be avoided.

\section{ACKNOWLEDGEMENTS}

The authors are grateful for the assistance of, and the helpful discussions with Sam Fink, David Hobbs, Sharon Marra, Carol Jantzen, and Major Thompson, from SRS, Harry Harmon, from Tank Focus Area, and John Plodinec from Mississippi State University. This work was supported by the Office of Environmental Management of the U.S. Department of Energy through the Efficient Separations and Processing (ESP) Program and the Tank Focus Area (TFA) of the Office of Science and Technology under Contract W-31-109-Eng-38 with Argonne National Laboratory, managed by the University of Chicago.

\section{REFERENCES}

FINK-2002

Private communications with Samuel Fink, SRS, April, 2002

HARMON-2002

H. D. Harmon, "Salt Processing Project Update and Lessons Learned", presented at the TFA Mid-Year Review Meeting, Salt Lake City, UT, March 11-13, 2002.

HOBBS-1992

D. T. Hobbs and D. D. Walker, "Plutonium and Uranium Adsorption on Mono-Na Titanate", WSRC-RP-92-93, August 13, 1992.

HOBBS-1993

D. T. Hobbs and S. D. Fleischman, "Fissile Solubility and Mono-Na Titanate Loading Tests", WSRC-RP-92-1273, February 12, 1993. 
HOBBS-1999

D. T. Hobbs, M. G. Bronikowski, T. B. Edwards, and R. L. Pulmano, "Final Report of Phase III Testing of MonoNa Titanate Adsorption Kinetics", WSRC-TR-99-00134, Rev. 0, May 28, 1999.

HOBBS-2002

Private communications with David Hobbs, SRS, April, 2002.

MARRA-2002

Private communications with Sharon Marra, SRS, April, 2002.

PLODINEC-2002

Private communications with John Plodinec, Mississippi State University, April, 2002 


\section{APPENDIX A. SRS RECIPE FOR WASTE SIMULANT PREPARATION}

\section{PROCEDURE:}

1. Prepare stock solution of $\mathrm{Na} 2 \mathrm{CO} 3$ as described below.

2. In a $4 \mathrm{~L}$ PE bottle, place approximately $2 \mathrm{~L}$ of $\mathrm{DDI} \mathrm{H} 2 \mathrm{O}$ and the indicated amount of Ultrex nitric acid.

3. Stir until well mixed and cool to room temperature.

4. Add the indicated amount of $\mathrm{Al}(\mathrm{NO} 3) 3.9 \mathrm{H} 2 \mathrm{O}$. Add the indicated amounts of $\mathrm{U}, \mathrm{Pu}, \mathrm{Np}$ and $\mathrm{Sr}-85$.

5. Slowly add the indicate amount of the $50 \mathrm{wt} \% \mathrm{NaOH}$ solution with vigorous mixing until a white precipitate persists. Add the remainder of the $\mathrm{NaOH}$ solution rapidly with vigorous mixing.

6. Add the remainder of the salts followed by the $\mathrm{Na} 2 \mathrm{CO} 3$ solution and mix for a minimum of 24 hours.

7. Filter through Whatman filter paper to remove undissolved solids. Limit exposure to air during filtration.

8. Store solution in tightly stoppered PE bottle labeled with name, date prepared, concentration and safety hazard warning after flushing vapor volume with nitrogen or argon.

\begin{tabular}{|c|c|c|c|c|c|c|}
\hline \multirow{9}{*}{ Final Soln Vol $(L)=$} & \multirow{2}{*}{\multicolumn{2}{|c|}{$\begin{array}{l}\text { Soln Conc } \\
\text { (M) }\end{array}$}} & & & & \\
\hline & & & & & & \\
\hline & Free $\mathrm{NaOH}$ & $1.33 \mathrm{E}+00$ & & & & \\
\hline & Total NaNO3 & $2.60 \mathrm{E}+00$ & & & & \\
\hline & $\mathrm{NaAl}(\mathrm{OH}) 4$ & 4.29E-01 & & & & \\
\hline & $\mathrm{NaNO} 2$ & $1.34 \mathrm{E}-01$ & & & & \\
\hline & $\mathrm{Na} 2 \mathrm{SO} 4$ & $5.21 \mathrm{E}-01$ & & & & \\
\hline & $\mathrm{Na} 2 \mathrm{CO} 3$ & $2.60 \mathrm{E}-02$ & & & & \\
\hline & Total $\mathrm{Na}$ & 5.6 & & & & \\
\hline COMPONENT & $\begin{array}{l}\text { Conc Acid } \\
\text { (M) }\end{array}$ & $\begin{array}{l}\text { Soln Conc } \\
\text { (M) }\end{array}$ & $\begin{array}{c}\text { Conc Acid } \\
(\mathrm{g})\end{array}$ & $\begin{array}{c}\text { Meas. Wt. } \\
\text { (g) }\end{array}$ & Manufacturer & Lot \# \\
\hline $\mathrm{HNO} 3$ & 15.9 & $1.31 \mathrm{E}+00$ & 469.0 & & & \\
\hline & $\begin{array}{c}\text { MW } \\
(\mathrm{g} / \mathrm{mole}) \\
\end{array}$ & $\begin{array}{l}\text { Soln Conc } \\
\text { (M) }\end{array}$ & $\begin{array}{l}\text { Salt Wt. } \\
\text { (g) }\end{array}$ & $\begin{array}{c}\text { Meas. Wt. } \\
\text { (g) }\end{array}$ & & \\
\hline $\mathrm{Al}(\mathrm{NO} 3) 3.9 \mathrm{H} 2 \mathrm{O}$ & 375.14 & 4.29E-01 & 643.7 & & & \\
\hline
\end{tabular}




\begin{tabular}{|c|c|c|c|c|c|c|}
\hline & $\begin{array}{c}\text { Stock Conc } \\
(\mu \mathrm{g} / \mu \mathrm{L})\end{array}$ & $\begin{array}{c}\text { Soln Conc } \\
(\mu \mathrm{g} / \mathrm{L})\end{array}$ & $\begin{array}{c}\text { Soln Vol. } \\
(\mu L)\end{array}$ & $\begin{array}{c}\text { Meas. Vol. } \\
(\mu \mathrm{L})\end{array}$ & & \\
\hline UNH Soln & 10 & 10000 & 4000 & & & \\
\hline Diluted Pu Soln & 1.93 & 200 & 415 & & & \\
\hline Diluted Np Soln & 2.68 & 500 & 746 & & & \\
\hline \multirow[t]{2}{*}{ Sr-85 Tracer } & see below & - & \#REF! & & & \\
\hline & & $\begin{array}{c}\text { Soln Conc } \\
\text { (g salt/g soln) }\end{array}$ & $\begin{array}{c}\text { Soln Wt (g) } \\
(g)\end{array}$ & $\begin{array}{c}\text { Meas. Wt. } \\
(\mathrm{g})\end{array}$ & Manufacturer & Lot \# \\
\hline $50 \mathrm{wt} \% \mathrm{NaOH}$ Solution & & 0.5 & 1395.2 & & & \\
\hline \multirow[t]{2}{*}{$\mathrm{NaCO} 3$ Solution } & & 0.1952 & 56.5 & & & \\
\hline & $\begin{array}{c}\text { MW } \\
\text { (g/mole) }\end{array}$ & $\begin{array}{c}\text { Concentration } \\
\text { (molar) }\end{array}$ & $\begin{array}{l}\text { Salt Wt. } \\
\text { (grams) }\end{array}$ & $\begin{array}{c}\text { Meas. Wt. } \\
\text { (grams) }\end{array}$ & Manufacturer & Lot \# \\
\hline $\mathrm{Na} 2 \mathrm{SO} 4.10 \mathrm{H} 2 \mathrm{O}$ & 322.19 & $5.21 \mathrm{E}-01$ & 671.4 & & & \\
\hline $\mathrm{NaNO} 2$ & 69 & 1.34E-01 & 37.0 & & & \\
\hline
\end{tabular}

Preparation of $\mathrm{Na2} \mathrm{CO} 3$ Solution

(prepare $10 \%$ excess of amount needed to allow for filtration losses)

\begin{tabular}{|c|c|c|c|c|c|c|}
\multicolumn{2}{c}{$\begin{array}{c}\text { MW } \\
\text { (g/mole) }\end{array}$} & $\begin{array}{c}\text { Qty } \\
\text { (moles) }\end{array}$ & $\begin{array}{c}\text { Salt Wt. } \\
\text { (grams) }\end{array}$ & $\begin{array}{c}\text { Meas. Wt. } \\
\text { (grams) }\end{array}$ & Manufacturer & Lot \# \\
\hline Na2CO3.H2O & 124.01 & $1.14 \mathrm{E}-01$ & 14.19 & & & \\
\hline
\end{tabular}

1. Dissolve indicated amount of $\mathrm{Na} 2 \mathrm{CO} 3$ in 100 grams of DDI water. Record weight of salt and water used.

2. Mix until all solids have dissolved. Add more water if necessary. Record weight of any additional water used.

3. Add $2.0 \mathrm{~g}$ of MST slurry (Optima Lot \# 33407 to bottle and mix at ambient laboratory temperature for a minimum of 48 hours. Record lot \# and quantity of MST used

4. Filter suspension through 0.45 micron disposable filter and store filtrate in clean PE bottle labeled as follows.

Sodium Carbonate Solution

Treated with MST to Remove Tramp Sr

Date Prepared: $\mathrm{mm} / \mathrm{dd} / \mathrm{yy}$ 
Distribution for ANL-02/30

Internal (Printed and Electronic Copies):

S. B. Aase

H. A. Arafat (5)

A. J. Bakel

D. B. Chamberlain

Y. I. Chang

V. A. Davis
M. L. Dietz

E. Freiberg

A. V. Guelis

J. E. Helt

R. A. Leonard

K. L. Nash
C. Pereira

M. C. Regalbuto

G. F. Vandegrift

S. K. Zussman

Internal (Electronic Copy Only):

D. L. Bowers

E. C. Gay

M. A. Buckley, Library-E

M. R. Hale, TIS

E. Sackett, Library-W

Library

D. Lewis

R. J. Finch

C. J. Mertz

J. Sedlet

M. J. Steindler

TIS Files

\section{External (Printed and Electronic Copies):}

Chemical Technology Division Review Committee Members:

H. U. Anderson, University of Missouri-Rolla, Rolla, MO

R. A. Greenkorn, Purdue University, West Lafayette, IN

C. L. Hussey, University of Mississippi, University, MS

M. V. Koch, University of Washington, Seattle, WA

V. P. Roan, Jr., University of Florida, Gainesville, FL

J. R. Selman, Illinois Institute of Technology, Chicago, IL

J. S. Tulenko, University of Florida, Gainesville, FL

J. F. Birdwell, Oak Ridge National Laboratory, Oak Ridge, TN

P. V. Bonnesen, Oak Ridge National Laboratory, Oak Ridge, TN

S. G. Campbell, Westinghouse Savannah River Company, Aiken, SC

J. T. Carter, Westinghouse Savannah River Company, Aiken, SC

S. Clifford, Westinghouse Savannah River Company, Aiken, SC

L. H. Delmau, Oak Ridge National Laboratory, Oak Ridge, TN

H. D. Harmon, Westinghouse Savannah River Company, Aiken, SC

G. Josephson, Battelle, Pacific Northwest National Laboratory, Richland, WA

R. T. Jubin, Oak Ridge National Laboratory, Oak Ridge, TN

J. D. Law, Idaho National Engineering and Environmental Laboratory, Idaho Falls, ID

R. Leugemors, Pacific Northwest National Laboratory, Richland, WA

G. J. Lumetta, Battelle, Pacific Northwest National Laboratory, Richland, WA

M. Maxted-Miles, DOE-SR, Aiken, SC

B. A. Moyer, Oak Ridge National Laboratory, Oak Ridge, TN

M. Norato, Westinghouse Savannah River Company, Aiken, SC

R. A. Pierce, Westinghouse Savannah River Company, Aiken, SC

P. C. Suggs, DOE-SR, Aiken, SC 
M. C. Thompson, Westinghouse Savannah River Company, Aiken, SC

T. A. Todd, Idaho National Engineering and Environmental Laboratory, Idaho Falls, ID

D. D. Walker, Westinghouse Savannah River Company, Aiken, SC

V. Wheeler, DOE-SR, Aiken, SC

\section{External (Printed Copy Only):}

C. Conner, BWX Technologies, Inc., Lynchburg, VA

K. D. Gerdes, DOE-EM, Tanks Focus Area Headquarters, Germantown, MD

T. P. Pietrok, USDOE, Richland Operations Office, Richland, WA

B. J. Williams, Pacific Northwest National Laboratory, Tanks Focus Area Technical Team, Richland, WA

\section{External (Electronic Copy Only):}

W. D. Clark, DOE-SR, Aiken, SC

S. M. Dinehart, Los Alamos National Laboratory, Los Alamos, NM

R. E. Edwards, Westinghouse Savannah River Company, Aiken, SC

S. D. Fink, Westinghouse Savannah River Company, Aiken, SC

D. Hobbs, Westinghouse Savannah River Company, Aiken, SC

C. Jantzen, WSRC, Aiken, SC

L. N. Klatt, Oak Ridge National Laboratory, Oak Ridge, TN

D. E. Kurath, Pacific Northwest National Laboratory, Richland, WA

K. T. Lang, USDOE, Washington, DC

S. Marra, WSRC, Aiken, SC

J. W. McCullough, USDOE, Aiken, SC

C. P. McGinnis, Oak Ridge National Laboratory, Oak Ridge, TN

A. L. Olson, Idaho National Engineering and Environmental Laboratory, Idaho Falls, ID

M. J. Palmer, Los Alamos National Laboratory, Los Alamos, NM

L. M. Papouchado, Westinghouse Savannah River Company, Aiken, SC

R. A. Peterson, Bechtel-Washington Process Technology, Richland, WA

B. M. Rapko, Pacific Northwest National Laboratory, Richland, WA

R. D. Rogers, University of Alabama, Department of Chemistry, Tuscaloosa, AL

K. J. Rueter, Bechtel-Washington Process Technology, Richland, WA

P. Rutland, Bechtel-Washington Process Technology, Richland, WA

S. Schlahta, Pacific Northwest National Laboratory, Richland, WA

J. L. Swanson, Richland, WA

W. L. Tamosaitis, Westinghouse Savannah River Company, Aiken, SC

L. L. Tavlarides, Syracuse University, Syracuse, NY

D. W. Tedder, Georgia Institute of Technology, Atlanta, GA

V. Van Brunt, University of South Carolina, Columbia, SC

J. F. Walker, Oak Ridge National Laboratory, Oak Ridge, TN

J. S. Watson, Oak Ridge National Laboratory, Oak Ridge, TN

R. M. Wham, Oak Ridge National Laboratory, Oak Ridge, TN

W. R. Wilmarth, Westinghouse Savannah River Company, Aiken, SC 